\title{
Eulogy for Professor Doğan Taner
}

\author{
İskender Sayek ${ }^{1,2}$ (D) , Erdal Akalın ${ }^{3}$ iD \\ ${ }^{1}$ Department of General Surgery (Emeritus), Faculty of Medicine, Hacettepe University, Ankara, Turkey \\ ${ }^{2}$ Association for Evahuation and Accreditation of Medical Education Programs (TEBDAD), Izmir, Turkey \\ ${ }^{3}$ Department of Internal Medicine (Emeritus), Faculty of Medicine, Hacettepe University, Ankara, Turkey \\ Anatomy 2021;15(1):95 @2021 Turkish Society of Anatomy and Clinical Anatomy (TSACA)
}

We were fortunate to have been students in the 1960's at Hacettepe University Medical School mainly because there was a spirit of compassion in every educator then. After graduation and specialty training we had a chance to work together as colleagues for many years with these outstanding educators. Among these educators Professor Doğan Taner was in a special position as a role model being a prominent educator, educationalist and administrator for all students.

\section{As an Educator}

As an educator Dr. Taner in the mid sixties taught us anatomy very enthusiastically and to learn in depth for our future carrier. He always acted as he preached his principles. He was a very strict educator, with discipline being his priority. But he was very affectionate, tender hearted and sincere to the students. We had always to be alert during his lectures or at the anatomy lab. In his lectures he impressed us as he taught functional anatomy in an interactive manner. Briefly we would like to state that he was a very good "role model" for us as an educator.

\section{As an Educationalist}

As a medical educationalist, he was one of the main leaders in Turkey to make a reform in medical education. In the sixties he was the pioneer to implement a system-organ based curriculum at Hacettepe Medical School. With his efforts system-organ based curriculum gained popularity in Turkish medical schools. He was one of those who implemented the concept of integration into medical education. After his retirement he continued his efforts to improve the quality of medical education in Turkey as a consultant in the Higher Educational Council.

\section{As an Administrator}

Initially he served as a Dean in the School of Health Sciences and later at Hacettepe University School of Medicine for a period over ten years. He combined his expertise as an educationalist with his administrative ability to improve the quality of medical education. As an administrator he was always devoted, fair and principle oriented.

We would like to stress that Dr. Taner was a good "role model" for us as an educator, educationalist and administrator. His efforts will be profoundly remembered as his students continue to practice or teach medicine.
ORCID ID:

I. Sayek 0000-0001-5951-3511; E. Akalın 0000-0001-9502-3480
Correspondence to: Iskender Sayek, MD

Association for Evaluation and Accreditation of Medical Education Programs

(TEBDAD), lzmir, Turkey

Phone: +903123052359

e-mail: isayek@gmail.com

Conflict of interest statement: No conflicts declared.

This is an open access article distributed under the terms of the Creative Commons Attribution-NonCommercial-NoDerivs 3.0 Unported (CC BY-NCND3.0) Licence (http://creativecommons.org/licenses/by-nc-nd/3.0/) which permits unrestricted noncommercial use, distribution, and reproduction in any medium, provided the original work is properly cited. Please cite this article as: Sayek I, Akalın E. Eulogy for Professor Doğan Taner. Anatomy 2021;15(1):95. 